J. Clin. Chem. Clin. Biochem.

Vol. 20, 1982, pp. 203-206

\title{
A New High Performance Liquid Chromatography (HPLC) Method for the Quantitation of Strychnine in Urine and Tissue Extracts
}

\author{
By Th. Egloff, A. Niederwieser, K. Pfister, A. Otten, B. Steinmann, W. Steiner and R. Gitzelmann
}

Divisions of Metabolism and Clinical Chemistry, Department of Pediatrics, University of Zürich, Switzerland

(Received August 11/December 16, 1981)

Summary: A high performance liquid chromatography (HPLC) method was developed for the quantitation of strychnine in urine of children with nonketotic hyperglycinaemia and other developmental disorders treated with the alkaloid. Mobile and stationary phases were polar, i.e. methanol-water-330 g/kg ammonia (volumes, $85 \mathrm{ml}+$ $14.2 \mathrm{ml}+0.8 \mathrm{ml}$ ) and LiChrosorb Si- $60,7 \mu \mathrm{m}$. Brucine was the internal standard. Extraction was performed by the Extrelut technique. At strychnine nitrate concentrations in urine of 21,126 , and $760 \mu \mathrm{g} / 1$, recovery was $92.1 \pm 8.7$, $98.1 \pm 2.7$, and $102.5 \pm 2.7 \%$. A child with nonketotic hyperglycinaemia under continued strychnine treatment excreted 1 to $13.6 \%$ of the daily dose unmetabolized in urine. The method was also suitable for the estimation of unreacted strychnine in tissue extracts. The fast disappearance in vitro of strychnine from a guinea pig liver preparation was confirmed.

\section{Eine neue Methode für die quantitative Bestimmung von Strychnin in Harn und Gewebsextrakten mit Hochleistungsflüssigkeitschromatographie (HPLC)}

Zusammenfassung: Zur Bestimmung von Strychnin im Harn von Kindern mit nicht-ketotischer Hyperglycinämie und anderen Entwicklungsstörungen, die mit dem Alkaloid behandelt werden, wurde eine Methode unter Verwendung der Hochleistungsflüssigkeitschromatographie (HPLC) entwickelt. Mobile und stationäre Phase waren polar, es wurden Methanol/Wasser $/ 330 \mathrm{~g} / \mathrm{kg}$ Ammoniak (Volumina, $85 \mathrm{ml}+14,2 \mathrm{ml}+0,8 \mathrm{ml}$ ) und LiChrosorb Si-60, $7 \mu \mathrm{m}$, verwendet. Brucin diente als innerer Standard. Die Extraktion wurde mit der Extrelut-Technik durchgeführt. Die Wiederfindung für Strychninnitrat-Konzentrationen im Harn von 21,126 und $760 \mu \mathrm{g} / 1$ betrug 92,1 $\pm 8,7,98,1 \pm 2,7$ und $102,5 \pm 2,7 \%$. Ein Kind mit nicht-ketotischer Hyperglycinämie schied unter kontinuierlicher Strychninbehandlung $1-13,6 \%$ der täglichen Dosis unverändert im Harn aus. Die Methode erwiẹ sich ebenso als geeignet für die Bestimmung von unverändertem Strychnin in Gewebsextrakten. Das schnelle Verschwinden von Strychnin aus einer Meerschweinchenleber-Präparation in vitro wurde bestätigt.

\section{Introduction}

Strychnine has a long history as a spinal analeptic but little is known of its metabolism. If given in repeated toxic doses to cats, dogs and guinea pigs, only a small amount is excreted in biologically active form in the urine, all of it within $24 \mathrm{~h}$ after the last dose (1). Unreacted strychnine is found in most tissues of cats and dogs and it is concentrated 6-7 fold in liver and kidney (2). In various animal species, the bulk of the drug is metabolized in the liver $(3,4)$, and it is not metabolized in gut, muscle, heart, kidney, brain or blood (4). In vitro transformation of strychnine by rabbit liver, measured with the methyl orange reaction, was apparently enzymatic; it occurred in microsomes enriched with soluble fraction, required $\mathrm{O}_{2}$ and NADPH, and had a narrow pH optimum at 8.4 (4). Phenobarbital and other inducing compounds given to rats and rabbits enhanced strychnine metabolism and lowered sensitivity $(5,6)$. Male rats had higher tolerance to strychnine than females (7). Of at least 4 metabolites produced by rabbit liver homogenates, only one was identified as 2 -hydroxystrychnine which in mice had a toxicity of only one hundredth of the parent alkaloid (6). Glucuronidation and sulfatation played only a minor role, if any, in the detoxification of strychnine by rabbit microsomes (4).

A few years ago, we initiated the treatment of children with nonketotic hyperglycinaemia and other developmental disorders with pharmacological doses of strychnine (8-11). Thus there arose the need to measure unreacted strychnine in urine and other biological fluids. Colour reactions (12), measurement of absorbance at one or two wavelengths after separation (13-15), double labeling techniques (16), GLC separation (17), and existing HPLC methods for grain baits (18) and drug 
mixtures $(19,20)$ were unsatisfactory in one or more respects. The interesting reversed phase HPLC method of Crouch \& Short (21) did not separate strychnine from brucine except by use of a solvent gradient. We developed a HPLC method which differs from the above (21) by making use of polar stationary and mobile phases and an isocratic solvent with brucine as the internal standard. Here we describe the procedure and its first applications.

\section{Materials and Methods}

Strychnine nitrate Ph. Helv. VI (Siegfried, Zofingen, Switzerland) $\left(M_{\mathrm{r}}\right.$ free strychnine $334.4 ; M_{\mathrm{r}}$ strychnine nitrate 397.4$)$; brucine $\cdot 2 \mathrm{H}_{2} \mathrm{O}$ p.a. $\left(M_{\mathrm{r}}\right.$ free brucine $394.4 ; M_{\mathrm{r}}$ brucine $\cdot$ $\left.2 \mathrm{H}_{2} \mathrm{O} 430.4\right)$, aqueous ammonia $33 \%(\mathrm{~d}=0.885)$, hexane p.a., and tetrahydrofuran Uvasol (Merck, Darmstadt, F.R.G.). Extrelut ${ }^{\circledR}$ for column extraction (Merck, F.R.G.). Equipment for HPLC: pump Altex 100 (Altex Scientific Inc., Berkeley Ca., USA), injector UGK and detector at $254 \mathrm{~nm}$ model 440 (Waters Associates Inc., Milford Ma., USA). HPLC column $(46 \times 250 \mathrm{~mm})$ and precolumn $(4.6 \times 40 \mathrm{~mm})$ were packed with LiChrosorb Si-60, $7 \mu \mathrm{m}$ (Knauer, Berlin F.R.G.), the stationary phase. The mobile phase was methanol-water- $330 \mathrm{~g} / \mathrm{kg}$ ammonia (volumes, $85 \mathrm{ml}+14.2 \mathrm{ml}+0.8 \mathrm{ml}$ ).

\section{Extraction}

A sample of $4 \mathrm{ml}$ urine was spiked with $100 \mu \mathrm{l}$ internal standard solution (brucine $\cdot 2 \mathrm{H}_{2} \mathrm{O}, 20 \mathrm{mg} / \mathrm{l}$ in methanol), adjusted to pH 12.0 with $3 \mathrm{~mol} / 1 \mathrm{NaOH}$ and applied to a column $(9 \mathrm{~cm} X$ $2.5 \mathrm{~cm}$ ) containing $4 \mathrm{~g}$ Extrelut. The sample was allowed to equilibrate with the Extrelut for $10 \mathrm{~min}$. Substances were eluted with $50 \mathrm{ml}$ dichloromethane and the total eluate was evaporated to dryness in vacuo. The residue was dissolved in $2 \times 0.5 \mathrm{ml}$ methanol, transfered to a small test tube and the methanol evaporated in a stream of nitrogen.

\section{Chromatography}

For HPLC the residue was dissolved in $50 \mu 1$ of mobile phase, and 1-5 $\mu \mathrm{l}$ were injected. The flow rate was $2.0 \mathrm{ml} / \mathrm{min}$. The elution was monitored at $254 \mathrm{~nm}$ with a detector sensitivity of 0.005 absorbance units on the full scale and a recorder sensitivity of $5 \mathrm{mV}$. The column was not stored in the mobile phase which was polar and basic. Instead, the column was rinsed with approx. $30 \mathrm{ml}$ of tetrahydrofuran followed by hexane as an inert solvent for storage. Before it was reused, the column was rinsed with at least $10 \mathrm{ml}$ of tetrahydrofuran followed by the mobile phase. By this treatment, the column was kept clean and could be used successfully and extensively for at least two months. The small dead volume which appeared at the top of the column bed after several months of use was filled with Li-Chrosorb Si-60 and the column employed further. (Theoretically one could avoid the formation of a dead volume by inserting a silica gel precolumn between pump and injector).

\section{Calculation}

The concentration of strychnine in the sample was calculated using the formula:

$$
c_{\text {strychnine }}=\mathrm{R} \cdot \mathrm{F} \cdot c_{\text {brucine }} \cdot 2 \mathrm{H}_{2} \mathrm{O}
$$

where $R$ was the peak height ratio, strychnine to brucine, at $254 \mathrm{~nm}$. Factor $\mathrm{F}$ was determined previously using the standard substances:

$$
\mathrm{F}=\frac{1}{\mathrm{R}} \cdot \frac{c_{\text {strychnine }}}{c_{\text {brucine }} \cdot 2 \mathrm{H}_{2} \mathrm{O}}
$$

Under our conditions it was 0.40 for free strychnine.

\section{Results and Discussion}

\section{Extraction and quantitation of strychnine}

For extraction of urines, solvents with higher polarity such as dichloromethane-isopropanol (volumes, $90 \mathrm{ml}$ $+10 \mathrm{ml}$ ) or ethyl-acetate offered the advantage of smaller volumes, but they resulted in tailings of $\mathrm{UV}$ absorbance ("solvent peaks"), which interfered with the strychnine peak. With toluene or benzene as the extraction solvents, the biological background was almost nil but brucine recovery was variable. The Extrelut technique (22) provided for excêllent recovery and low biological background. High urinary salt concentrations (up to $0.3 \mathrm{~mol} / 1$ sodium chloride added) did not impair the extraction.

For high performance liquid chromatogräphy, several solvents were tried as mobile phases, e.g. diethylether: methanol-diethylamine (20) and dichloromethanemethanol-diethylamine mixtures. With methanol- $\mathrm{H}_{2} \mathrm{O}$ $330 \mathrm{~g} / \mathrm{kg}$ ammonia (volumes, $85 \mathrm{ml}+14.2 \mathrm{ml}+0.8 \mathrm{ml}$ ), optimal resolution and the clearest background were obtained (number of theoretetical plätes $900=1200$ ). Several unspiked urines from healthy children and adults were processed, and peaks interfering with the position of strychnine and brucine were not observed (fig. 1b).

In order to evaluate the precision of the method, strychnine nitrate was added to a urine specimen of a control person at a concentration of $220 \mu \mathrm{g} / 1$, and $4 \mathrm{ml}$ portions were processed. The variation coefficient (VC) was $0.8 \%(n=12)$.

A linear calibration curve was obtained by the addition of strychnine nitrate to urine to yield concentrations of $20-840 \mu \mathrm{g} / \mathrm{l}$ (coefficient of correlation $\mathrm{r}=0.999$; $n=12$ ). The calibration curve matched the curves obtained from pure standards.

Recovery was tested by the addition of strychnine nitrate to control urines of 6 children at low $(21 \mu \mathrm{g} / 1)$, intermediate $(126 \mu \mathrm{g} / \mathrm{l})$ and high $(760 \mu \mathrm{g} / 1)$ concentrations. Recovery was $92.1 \pm 8.7,98.1 \pm 2.7$, and $102.5 \pm$ $2.7 \%$, respectively.

The detection limit was $2-4$ ng per injection; starting with a $4 \mathrm{ml}$ urine sample, this corresponded to a strychnine concentration of $5-10 \mu \mathrm{g} / 1$. When the urinary strychnine concentration exceeded $200 \mathrm{mg} / \mathrm{l}$, sämple size could be reduced.

Strychnine metābolites were not investigated in our study. It can be expected that they will not interferê with the measurement of strychinine. Because of their different polarity and molecular weight, they will either not be extracted or be separated from strychnine chromatographically.

\section{Application of the method}

Chromatograms of strychnine extracted from the urine of a child treated with the alkaloid and from a spiked

$$
\text { i }
$$

J. Clin. Chem. Clin. Biochem. / Vol. 20, 1982 / Nọ. 4 

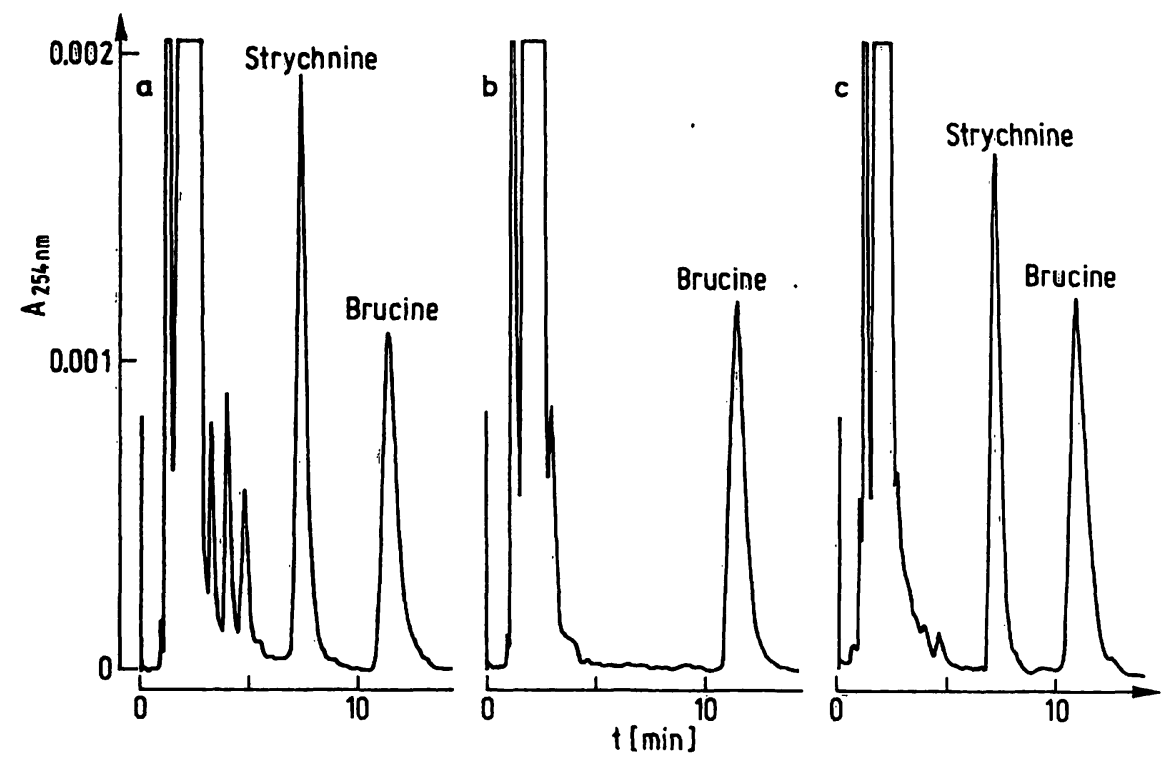

Fig. 1. HPLC of strychnine in human urine $(a, b)$ and in guinea pig liver extract (c).

Brucine $\cdot 2 \mathrm{H}_{2} \mathrm{O}(500 \mu \mathrm{g} / 1)$ was the internal standard. Column $(46 \times 250 \mathrm{~mm})$ and pre-column $(4.6 \times 40 \mathrm{~mm})$ of LiChrosorb $\mathrm{Si}-60,7 \mu \mathrm{m}$; mobile phase methanol-water- $330 \mathrm{~g} / \mathrm{kg}$ ammonia (volumes, $85 \mathrm{ml}+14.2 \mathrm{ml}+0.8 \mathrm{ml}$ ); flow rate $2 \mathrm{ml} / \mathrm{min}$

a) Urine of patient B.F.; injected volume: $3 \mu l$ of extract, equivalent to $0.24 \mathrm{ml}$ of urine.

b) Urine of a healthy control person without strychnine (otherwise same as a).

c) Supernatant of guinea pig liver extract after incubation; injected volume: $4 \mu \mathrm{l}$ of extract, equivalent to $0.32 \mathrm{ml}$ of diluted mixture (see fig. 2).

control urine are shown in figures $1 \mathrm{a}$ and $1 \mathrm{~b}$. Patient B.F. (8) suffering from nonketotic hyperglycinaemia and treated with daily oral strychnine nitrate for 3 years excreted from 1 to $13.5 \%$ of the drug unmetabolized (tab. 1). There was no correlation between the proportion of unmetabolized strychnine in urine and the duration of therapy or the administered dose. It is interesting that these results were in good agreement with those obtained many years ago in man (3) and in animals (1).

The method was also applied to tissue extracts (fig. 1c). An experiment published by Adamson \& Fouts (4) was

Tab. 1. Excretion of strychnine in $24 \mathrm{~h}$ urine of patiênt B.F. with nonketotic hyperglycinaemia (8) during continued treatment with oral strychnine nitrate.

\begin{tabular}{lcccc}
\hline Age & Weight & $\begin{array}{l}\text { Dose of } \\
\text { strychnine } \\
\text { nitrate }\end{array}$ & $\begin{array}{l}\text { Strychnine } \\
\text { excreted }\end{array}$ & $\begin{array}{l}\text { Percent of } \\
\text { administered } \\
\text { strychnine in } \\
\text { 24 h-urine }\end{array}$ \\
(a) & $(\mathrm{kg})$ & (mg/d) & $(\mu \mathrm{g} / 24 \mathrm{~h})$ & \\
\hline $6 / 12$ & 7.5 & 1.2 & $\begin{array}{r}18.9 \\
* 19.9\end{array}$ & 1.9 \\
$7 / 12$ & 7.8 & 3.2 & $\begin{array}{r}29.3 \\
* 23.7\end{array}$ & 1.0 \\
$7 / 12$ & 8.0 & 1.8 & $\begin{array}{r}26.3 \\
* 18.3\end{array}$ & 1.5 \\
$8 / 12$ & 8.9 & 3.0 & $\begin{array}{r}11.6 .3 \\
* 112.0\end{array}$ & 4.6 \\
3 & 11.5 & 12.8 & 335.0 & 3.1 \\
$31 / 2$ & 12.1 & 12.8 & 1475.0 & 13.6 \\
\hline
\end{tabular}

* Values obtained from a second extraction and chromatography done after the samples had been kept at $-20^{\circ} \mathrm{C}$ for 1 year. duplicated and the disappearance of unreacted strychnine in a guinea pig liver microsome preparation followed (fig. 2). Strychnine concentration fell in a first order mode to one tenth of the initial concentration at a rapid rate ( $50 \%$ disappearance in $16 \mathrm{~min})$. The suitability of the method for the quantitation of strychnine in tissue extracts was thus estäblished.

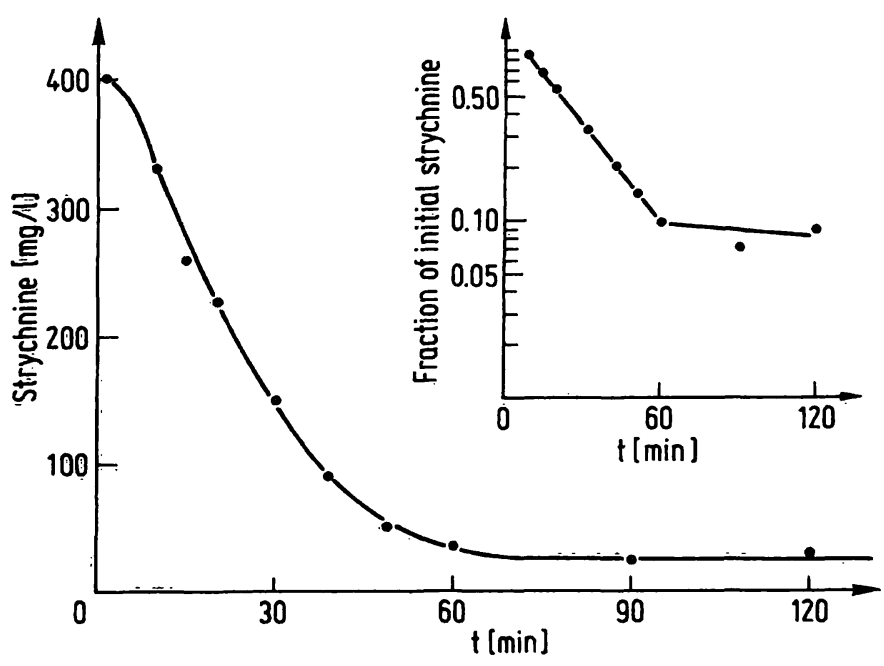

Fig. 2. Metabolism of strychnine by guinea pig liver microsomal preparation in vitro.

Supernatant, $9000 \mathrm{~g}$, from $1.2 \mathrm{~g}$ of liver (1:4 homogenate in $0.15 \mathrm{~mol} / 1 \mathrm{KCl}$ ) was incubated at $37^{\circ} \mathrm{C}$ in a Warburg apparatus under oxygen with 12 moles of strychnine nitrate in $0.12 \mathrm{~mol} / 1$ Tris- $\mathrm{HCl}$ pH 8.2. Initial concentrations of cofactors were: nicotinamide $40 \mathrm{mmol} / 1$, NADP $55 \mu \mathrm{mol} / 1$, glucose-6-phosphate $5 \mathrm{mmol} / 1$. Volume was $12 \mathrm{ml}$. At the times indicated, $0.6 \mathrm{ml}$ aliquots were withdrawn, denatured for $2 \mathrm{~min}$ at $100^{\circ} \mathrm{C}$, centrifuged, diluted with water 800 times, and $4 \mathrm{ml}$ of diluted mixture were processed for strychnine extraction and chromatography. 


\section{References}

1. Hatcher, R. A. \& Eggleston, C. (1917) J. Pharmacol. Exp. Ther. 10, 281-319.

2. Veit, F. (1935) Arch. Exp. Pathol. 178, 593-602.

3. Weiss, S. \& Hatcher, R. A. (1922) J. Pharmacol. 19, 419482.

4. Adamson, R. H. \& Fouts, J. R. (1959) J. Pharmacol. Exp. Ther. 127, 87-91.

5. Kato, R., Chiesara, E. \& Vassanelli, P. (1962) Biochem. Pharmacol. 11, 211-220.

6. Tsukamoto, H., Oguri, K., Watabe, T. \& Yoshimura, H. (1964) J. Biochem. 55, 394-400.

7. Kato, R., Chiesara, E. \& Vassanelli, P. (1962) Jap. J. Phar= macol. 12, 26-33.

8. Gitzelmann, R., Steinmann, B., Otten, A., Dumermuth, G., Herdan, M., Reubi, J. C. \& Cuénod, M. (1977) Hèlv. Paediat. Acta $32,517-525$.

9. Gitzelmann, R., Steinmann, B. \& Cuénod, M. (1978) N. Engl. J. Med. 298, 1424.

10. Gitzelmann, R., Boltshauser, E., Steinmann, B. \& Weber, M. (1979) Helv. Paediat. Acta, Suppl. 42, 11 (Abstr.).

11. Steinmann, B. \& Gitzelmann, R. (1979) Helv. Paediat. Acta 34, 589-599.

12. Axelrod, J. (1954) J. Pharmacol. Exp. Ther. 110, 315-326.
13. Sgaragli, G. P. \& Mannaiōni, P. F. (1973) Clin. Toxicol. 6, $533-540$.

14. Scott, M., Taub, A. \& Piantadosi, C. (1956) Jे. Amer. Pharm. Assoc. 45, 232-236.

15. El-Masry, S. \& Wahbi, A.-A. M. (1978) J. Assoc. Öf. Anal. Chem. 61, 65-67.

16. Wiley, R. A. \& Metzger, J. L. (1967) J. Phąrmacol. Sc̈i. 56, $144-145$.

17. Hanks, A. R., Engdahl, B. S. \& Colvin, B. M. (1975) J. Assoc. Off. Anal. Chem. 58, 961-964.

18. Bushway, R. J., Cramer, C. W., Hanks, A. R. \& Colvin, B. M. (1975) J. Assoco. Off. Anal. Chem. 58, 957-960.

19. Achari, R. G. \& Theimer, E. E. (1977) J. Chromatographic Sci. $15,320-21$.

20. Chromatographie MẼRĊ̇, High Pèrförmañce Liquid Chromatography, Application of LiChrosorb, LiChrospher, Perisorb, Hibar Pre-packed Columns, E. Mèrck, Darmstadt, FRG 1978.

21. Cŕouch, M. D. \& Short, C. R. (1978) J. Assoc. Off. Anal. Chem. 61, 612-615.

22. Breiter, J., Helger, R. \& Lang, H. (1976) Forens. Sci. 7, 131-140.
Prof. R. Gitz̄elmañn

Kinderspital

Steinwiesstr. 75

CH-8032 Zürich 